\title{
Kombinasi Artemisinin dan Ekstrak Moringa oleifera Menurunkan Ekspresi NF-kB namun Tidak Menurunkan Ekspresi iNOS pada Otak Mencit Diinfeksi Malaria
}

\section{Combination of Artemisinin and Moringa oleifera Extract Reduces NF-KB but not iNOS Expressions in Malaria-infected Mice's Brain}

\author{
Herpan Syafii $\mathrm{H}^{1}$, Mochammad Dalhar ${ }^{2}$, Tinny Endang $\mathrm{H}^{3}$, Eviana Norahmawati ${ }^{4}$, Loeki E Fitri ${ }^{5}$ \\ ${ }^{1}$ Program Studi Magister IImu Biomedik Fakultas Kedokteran Universitas Brawijaya Malang \\ ${ }^{2}$ Laboratorium Neurologi Rumah Sakit Umum Daerah Dr. Saiful Anwar Malang \\ ${ }^{3}$ Laboratorium Patologi Klinik Rumah Sakit Umum Daerah Dr. Saiful Anwar Malang \\ ${ }^{4}$ Laboratorium Patologi Anatomi Rumah Sakit Umum Daerah Dr. Saiful Anwar Malang \\ ${ }^{5}$ Laboratorium Parasitologi Fakultas Kedokteran Universitas Brawijaya Malang
}

\begin{abstract}
ABSTRAK
Malaria otak merupakan manifestasi tersering dari infeksi malaria berat yang ditandai dengan respon inflamasi berlebih di otak. Untuk mencegah terjadinya resistensi, penggunaan obat antimalaria standar (artemisinin) harus dikombinasikan dengan obat antimalaria lain. Moringa oleifera, yang secara in vitro memiliki aktivitas antimalaria dan anti-inflamasi, merupakan kandidat obat untuk dikombinasikan dengan artemisinin. Penelitian dilakukan untuk menguji pengaruh kombinasi artemisinin dan ekstrak Moringa oleifera terhadap ekspresi NF-kB dan iNOS pada otak mencit model malaria. Penelitian eksperimental laboratorik ini dilakukan dengan menggunakan 36 ekor mencit Balb/C yang diinfeksi Plasmodium berghei ANKA sebagai model malaria. Sampel dibagi menjadi enam kelompok, masing-masing satu kelompok kontrol positif, kontrol negatif, pemberian artemisinin 0,12mg/hari (C0), dan tiga kelompok yang masingmasing mendapatkan kombinasi artemisinin 0,12 mg/hari dan ekstrak daun kelor 3,75mg/hari (C1), 7,5mg/hari (C2) dan $15 \mathrm{mg} /$ hari (C3). Pengobatan diberikan setelah mencit mencapai derajat parasitemia 1-5\% pasca inokulasi parasit secara intraperitoneal. Ekspresi NF-kB dan iNOS otak mencit diamati dengan metode imunohistokimia pada hari ke-3 dan ke-7 pasca infeksi. Pemberian kombinasi artemisinin 0,12mg/hari dan ekstrak Moringa oleifera 3,75mg/hari, 7,5mg/hari, dan $15 \mathrm{mg} /$ hari, menyebabkan penurunan ekspresi NF-kB dan iNOS yang bermakna dibandingkan dengan kontrol positif $(p<0,05)$. Perlakuan tersebut tidak menyebabkan penurunan ekspresi iNOS yang bermakna dibandingkan pemberian artemisinin $0,12 \mathrm{mg} /$ hari saja $(p>0,05)$. Kombinasi ekstrak Moringa oleifera dengan artemisinin memberikan efek sinergis dalam penurunan derajat parasitemia dan ekspresi NF-kB, tetapi tidak untuk ekspresi iNOS di otak mencit yang diinfeksi malaria.
\end{abstract}

Kata Kunci: Artemisinin, iNOS, malaria otak, Moringa oleifera, NF-kB

\begin{abstract}
Cerebral malaria is the most frequent manifestation of severe malaria infection characterized by excessive inflammatory response in the brain. In preventing resistance, the use of standard antimalaria drug (Artemisinin) needs combining with other antimalaria drugs. In vitro, Moringa oleifera has antimalaria activities and anti-inflammatory and is a candidate drug combined with artemisinin. This research is conducted to test the effect of artemisinin and Moringa oleifera combination towards NF-KB and iNOS expressions in mice's brain of malaria model. This experimental laboratory study used 36Balb/C mice infected by Plasmodium berghei ANKA strain as malaria model. They were divided into six groups, namely a group of positive control, a group of negative control, a group of mice treated with artemisinin 0,12mg/day (CO), and three groups treated with combination of artemisinin 0,12mg/day and Moringa oleifera extract 3,75mg/day (C1), $7,5 \mathrm{mg} /$ day (C2), and 15mg/day (C3). The treatment was started when parasitemia reached 1-5\% after intra-peritoneal parasite inoculation. NF-KB and iNOS expressions in mice's brain were measured using immunohistochemistry method on day-3 and day-7 post treatment. Administration of combination between artemisinin 0,12mg/day and Moringa oleifera extract $3,75 \mathrm{mg} /$ day, $7,5 \mathrm{mg} /$ day, and $15 \mathrm{mg} /$ day significantly decreased the expression of NF- $\mathrm{kB}$ and iNOS compared to the positive control $(p<0,05)$, but did not cause a significant reduction in iNOS expression compared to administration the artemisinin of $0,12 \mathrm{mg} /$ day only $(p>0,05)$. The combination of artemisinin and extracts of Moringa oleifera provides a synergistic effect in decreasing the degree of parasitemia and the expression of NF-KB, but not for the iNOS expression in brain of mice infected malaria.
\end{abstract}

Keywords: Artemisinin, iNOS, cerebral malaria, Moringa oleifera, NF-kB

Jurnal Kedokteran Brawijaya, Vol. 28, No. 3, Februari 2015; Korespondensi: Loeki E Fitri. Laboratorium Parasitologi Fakultas Kedokteran Universitas Brawijaya Malang, Jl. Veteran Malang Indonesia Phone. (0341) 569117Email: lukief@ub.ac.id 


\section{PENDAHULUAN}

Malaria merupakan masalah kesehatan global. Menurut data WHO pada tahun 2011, diperkirakan sebanyak 3,3 juta penduduk dunia rentan terinfeksi malaria (1). Saat ini terdapat lima spesies Plasmodium yang diketahui dapat menginfeksi manusia, yaitu Plasmodium $(P)$. falciparum, $P$. vivax, P. ovale, P. malariae, dan P. Knowlesi $(1,2)$. Plasmodium falciparum merupakan penyebab malaria berat, termasuk malaria serebral (1).

Hingga sekarang diketahui bahwa patogenesis dasar untuk terjadinya malaria serebral meliputi serangkaian proses yang terdiri dari adhesi eritrosit terinfeksi $P$. falciparum pada sel endotel (cytoadherence), pada eritrosit normal (rossetting), atau pada eritrosit terinfeksi (autoagglutination), dan diikuti dengan sekuestrasi parasit kedalam jaringan otak. Kerusakan sawar darahotak fokal akibat serangkaian proses tersebut menyebabkan terpaparnya sel neuron dan glia perivaskuler dengan sitokin yang berasal dari sirkulasi sistemik (3). Kondisi tersebut akan menyebabkan peningkatan respon inflamasi di jaringan otak yang dimediasi oleh aktivasi nuclear factor-kB (NF-kB) dan produksi inducible nitric oxide synthase (iNOS) (4). Peningkatan iNOS akan meningkatkan kadar nitric oxide (NO), yang selanjutnya akan menginduksi terjadinya kematian sel (5).

Artemisinin adalah salah satu obat anti malaria dari golongan sesquiter-penelectone, suatu endoperoksidase yang saat ini digunakan untuk pengobatan malaria berat (7). Artemisinin merupakan antimalaria yang kuat dan bekerja dengan onset cepat (6). Aktivitas antimalaria artemisinin melibatkan dua tahap, yaitu aktivasi rantai endoperoksida dan pembentukan carbon-centered radical yang memiliki aktivitas antimalaria (8).

Artemisinin merupakan komponen utama dalam strategi terapi kombinasi untuk malaria yang resisten terhadap obat antimalaria konvensional (7). Untuk mencegah terjadinya resistensi terhadap artemisinin, WHO merekomendasikan penggunaan Artemisinin-based Combination Therapy (ACT) (6). Berbagai upaya dilakukan untuk menemukan obat antimalaria baru yang mampu meningkatkan efektivitas obat antimalaria yang ada saat ini (9).

Moringa oleifera (daun kelor) merupakan salah satu tanaman tradisional yang dipercaya memiliki aktivitas antimalaria. Moringa oleifera secara in vitro memiliki aktivitas skizontisid terhadap P. Falciparum (9). Moringa oleifera juga mengandung senyawa fenol. Senyawa fenol diketahui mampu menurunkan aktivasi NF-kB dan iNOS secara berlebihan di jaringan otak dan mencegah komplikasinya (10). Kadar senyawa fenol yang terkandung dalam ekstrak Moringa oleifera sekitar 118 mg/g (11). Penelitian ini bertujuan untuk mengetahui efek sinergis pemberian terapi kombinasi artemisinin dan ekstrak Moringa oleifera terhadap ekspresi NF-kB dan iNOS pada jaringan otak mencit yang diinfeksi Plasmodium berghei ANKA.

\section{METODE}

\section{Desain Penelitian}

Penelitian eksperimental laboratorium dikerjakan dengan menggunakan 36 ekor mencit Balb/C yang diinfeksi Plasmodium berghei ANKA sebagai model malaria. Sampel dibagi menjadi enam kelompok, yaitu satu kelompok kontrol negatif (kelompok mencit yang tidak diinfeksi Plasmodium berghei ANKA dan tidak diberi pengobatan), satu kelompok kontrol positif (kelompok mencit yang diifeksi Plasmodium berghei ANKA tanpa diberikan pengobatan), dan empat kelompok mencit perlakuan, yaitu kelompok mencit yang diinfeksi Plasmodium berghei ANKA secara intra-peritoneal dan diberi pengobatan, masing-masing dengan artemisinin $0,12 \mathrm{mg} /$ hari (CO), kombinasi artemisinin $0,12 \mathrm{mg} /$ hari dan ekstrak Moringa oleifera 3,75mg/hari (C1), 7,5mg/hari (C2), dan $15 \mathrm{mg} /$ hari (C3). Pengobatan mulai diberikan ketika derajat parasitemia mencapai $1-5 \%$ setelah inokulasi $10^{7}$ parasit dalam medium RPMI secara intraperitoneal, masing-masing selama tiga hari dan tujuh hari. Ekspresi NF-kB dan iNOS diukur dengan menggunakan metode imunohistokimia. Derajat parasitemia diukur pada hari ke-3 dan ke-7 paska pengobatan.

\section{Model Hewan Coba}

Model hewan coba yang digunakan dalam penelitian ini adalah mencit Balb/c jantan dengan berat 20-40 gram, sehat, aktif, dan berwarna putih, yang dibeli dari Pusvetma Surabaya sebanyak 41 ekor. Sebanyak 5 ekor diantaranya digunakan sebagai mencit donor. Mencit ditempatkan didalam kandang berukuran $30 \times 30 \mathrm{~cm}$ yang berisi 5 mencit untuk tiap kandang. Mencit diadaptasikan selama 7 hari dan setiap hari diberikan makan dan minum standar. Penelitian ini telah mendapatkan persetujuan dari Komisi Etik Fakultas Kedokteran Universitas Brawijaya dengan nomor surat persetujuan etik 103/EC/KEPK-S2/02/2013

\section{Persiapan Ekstrak Moringa oleifera}

Ekstraksi daun Moringa oleifera terdiri dari tiga proses, yaitu proses pengeringan, ekstraksi, dan evaporasi. Pada proses pengeringan, daun Moringa oleifera dicuci, dipotong-potong, dan dipanaskan pada suhu $80 \mathrm{C}$ sampai kering. Pada proses ekstraksi, daun Moringa oleifera dihaluskan dan ditimbang sampai didapatkan berat 100 gram. Sampel selanjutnya ditempatkan didalam gelas erlenmeyer dan direndam etanol selama semalam. Pada proses evaporasi, lapisan teratas dari sampel yang telah direndam semalam diambil dan ditempatkan kedalam evaporator bersuhu $90^{\circ} \mathrm{C}$. Bahan aktif yang diekstrak dari proses tersebut ditempatkan dalam gelas penampung dan dikirim ke Laboratorium Penelitian dan Pengujian Terpadu (LPPT) Universitas Gadjah Mada untuk dilakukan pemeriksaan kromatografi lapis tipis. Pemeriksaan ini dilakukan untuk mengetahui kandungan fenol dalam ekstrak Moringa oleifera (11).

\section{Persiapan dan Inokulasi P. berghei ANKA}

Plasmodium berghei ANKA didapatkan dari Laboratorium Biomedik Universitas Brawijaya. Eritrosit mencit yang terinfeksi $P$. berghei ANKA dan tersimpan dalam tabung nitrogen cair dicairkan, dan secara berturut-turut ditambah dengan $\mathrm{NaCl} 12 \%$ dan $\mathrm{NaCl} 1,6 \%$. Isolat tersebut selanjutnya diinkubasikan selama 5 menit dan disentrifus dengan kecepatan 2000 rpm selama 5 menit. Pelet yang diperoleh dilarutkan dalam medium RPMI untuk inokulasi $10^{7}$ parasit dalam $0,2 \mathrm{ml}$ darah untuk tiap mencit secara intra-peritoneal (12). Parasitemia diperiksa dengan metode hapusan darah tipis dengan pewarnaan Giemsa. Derajat parasitemia diukur dengan cara menghitung jumlah eritrosit terinfeksi per 1000 eritrosit (dihitung dengan hand counter). Pengamatan derajat parasitemia dilakukan oleh 2 orang pemeriksa dengan label pada slide yang menunjukkan kelompok sampel yang diperiksa tidak diketahui oleh 2 orang pemeriksa tersebut. 


\section{Persiapan Sampel Otak Mencit}

Dilakukan eutanasia pada mencit dengan menggunakan kloroform pada hari ke-3 dan ke-7 paska pengobatan. Jaringan otak mencit segera diambil dan ditempatkan kedalam tabung berisi larutan formalin $10 \%$. Proses pengirisan dan pembuatan sediaan yang akan digunakan dalam prosedur imunohistokimia dikerjakan di Laboratorium Patologi Anatomi Rumah Sakit Dr. Soetomo Surabaya.

\section{Imunohistokimia}

Irisan sampel yang telah disiapkan untuk pemeriksaan ekspresi NF-kB dan iNOS pada hari ke-3 dan ke-7 dipanaskan pada suhu $60 \mathrm{C}$ selama 60 menit dan secara berturut-turut ditetesi dengan xylol, etanol absolut, etanol $90 \%$, etanol $80 \%$, etanol $70 \%$, dan larutan akuades. Irisan sampel direndam dalam tabung berisi buffer citrate dengan $\mathrm{pH}$ 6,0, dan selanjutnya tabung tersebut direndam dalam air bersuhu 95C selama 20 menit. Selanjutnya irisan sampel diinkubasikan selama 15 menit, dilakukan proses blocking dari protein nonspesifik, diinkubasikan dengan antibodi primer anti-NF-kB/p65 (LOT: 1638P803I, NeoMarkers) selama semalam pada suhu 4C. Proses selanjutnya irisan sampel dilakukan inkubasi dengan antibodi sekunder (Dako LSAB + System-HRP) selama 60 menit pada suhu ruang, dengan SA-HRP (Dako LSAB + System-HRP) selama 60 menit pada suhu ruang. Diantara prosedur-prosedur tersebut, irisan sampel dibilas dengan phosphate-buffered saline (PBS). Terakhir, irisan sampel ditetesi dengan DAB (Dako LSAB+System-HRP) dan diberi warna latar dengan Hematoxilen. Prosedur imunohistokimia yang sama juga digunakan utuk iNOS, kecuali untuk penggunaan anti-NOS2 sebagai antibodi primer (L1510, Santa Cruz Biotechnology). Prosedur diatas merupakan prosedur pemeriksaan imunohistokia standar di Laboratorium Biomedik Fakultas Kedokteran Universitas Brawijaya.

\section{Analisis Data}

Analisis data dikerjakan dengan menggunakan SPSS 17 dengan uji t-independent, uji Mann-Whitney, uji One Way ANOVA, uji post hoc Tukey, dan uji Kruskal-Wallis. Hasil uji bermakna jika nilai $p<0,05$.

\section{HASIL}

\section{Derajat Parasitemia}

Uji t-independen untuk rerata derajat parasitemia pada hari ke-3 dan ke-7 dikerjakan untuk kelompok kontrol positif, C0, dan C1. Uji Mann-Whitney rerata derajat parasitemia pada hari ke-3 dan ke-7 dikerjakan untuk kelompok C2 dan C3. Data tersebut menunjukkan terdapat perbedaan rerata derajat parasitemia yang bermakna antara hari ke-3 dan hari ke-7 pada kelompok C1 $(p=0,000), C 2(p=0,046)$, dan C3 $(p=0,046)$. Tidak didapatkan perbedaan yang bermakna pada kelompok kontrol positif $(p=0,127)$ dan CO $(p=0,127)$. Uji One Way ANOVA untuk derajat parasitemia diantara berbagai kelompok pada hari ke-3 menunjukkan perbedaan bermakna $(p=0,000)$. Uji post hoc Tukey menunjukkan perbedaan rerata derajat parasitemia yang bermakna antara kelompok kontrol positif dan $\mathrm{CO}(\mathrm{p}=0,033)$, kontrol positif dan $\mathrm{C} 1(p=0,001)$, kontrol positif dan $\mathrm{C} 2(p=0,000)$, dan kontrol positif dan C3 $(p=0,000)$. Tidak didapatkan perbedaan yang bermakna antara kelompok CO dan C2 $(p=0,033)$, C0 dan C3 ( $p=0,008)$, dan C2 dan C3 $(p=0,381)$. Hasil tersebut menunjukkan bahwa diantara semua kelompok pengobatan, kombinasi artemisinin $0,12 \mathrm{mg} /$ hari dan ekstrak Moringa oleifera $7,5 \mathrm{mg} /$ hari (C2), dan $15 \mathrm{mg} /$ hari (C3) paling efektif menurunkan derajat parasitemia.

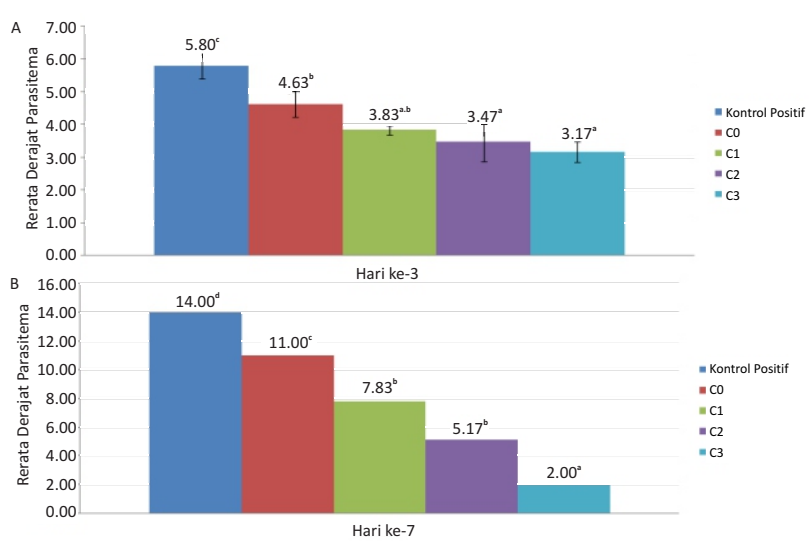

Gambar 1. Efektivitas kombinasi artemisinin dan ekstrak Moringa oleifera dalam menurunkan derajat parasitemia.

Keterangan: A.) Pengamatan hari ke-3 dan B.) Pengamatan hari ke-7

\section{Ekspresi NF-KB}

Uji t-independen untuk rerata ekspresi NF-kB jaringan otak mencit antara hari ke-3 dan ke-7 untuk tiap kelompok pengobatan menunjukkan perbedaan yang bermakna pada C2 $(p=0,028)$ dan C3 $(p=0,024)$. Tidak didapatkan perbedaan yang bermakna pada kelompok kontrol positif $(p=0,657), C 0(p=0,057), C 1(p=0,075)$, dan kontrol negatif $(p=0,770)$. Uji One Way ANOVA untuk ekspresi NF-kB diantara berbagai kelompok pada hari ke-3 menunjukkan perbedaan yang bermakna $(p=0,000)$. Uji post hoc Tukey menunjukkan perbedaan ekspresi NF-kB yang bermakna antara kelompok kontrol positif dan CO $(p=0,000)$, kontrol positif dan $\mathrm{C} 1(\mathrm{p}=0,000)$, kontrol positif dan $\mathrm{C} 2(\mathrm{p}=0,000)$, dan kontrol positif dan C3 $(p=0,000)$. Tidak didapatkan perbedaan yang bermakna antara kelompok $\mathrm{CO}$ dan $\mathrm{C} 1$ $(p=0,991)$, CO dan C2 ( $p=0,231)$, dan C0 dan C3 $(p=0,121)$. Hasil tersebut menunjukkan bahwa semua kelompok pengobatan pada pengamatan hari ke-3 memiliki efektivitas yang sama dalam menurunkan ekspresi NF-kB.

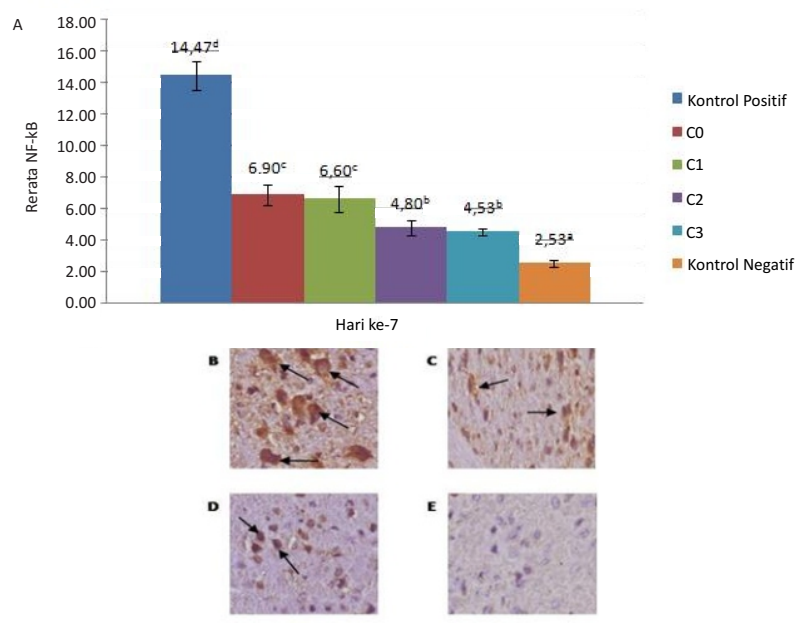

Gambar 2. Efektivitas komnbinasi artemisinin dan ekstrak Moringa oleifera dalam menurunkan ekspresi NF-kB. 


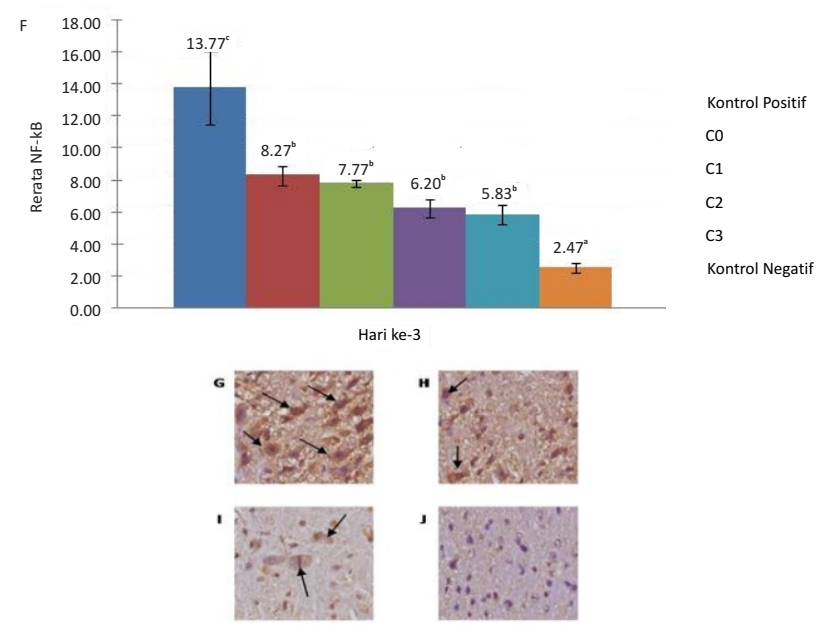

Gambar 2. Efektivitas komnbinasi artemisinin dan ekstrak Moringa oleifera dalam menurunkan ekspresi NF-kB. (lanjutan)

\section{Keterangan:}

Mencit diberikan pengobatan artemisinin $0,12 \mathrm{mg} /$ hari (C0), kombinasi artemisinin 0,12mg/hari dan ekstrak Moringa oleifera 3,75mg/hari (C1), 7,5mg/hari (C2), dan $15 \mathrm{mg} /$ hari (C3), masing-masing pengobatan diberikan selama 3 hari dan 7 hari.

Grafik A. Pengamatan hari ke-3 ; F. Pengamatan hari ke-7

Pemeriksaan imunohistokimia ekspresi NF-kB pada hari ke-3: Gambar (B) kelompok kontrol positif; (C) kelompok CO, (D) kelompok C3, dan (E) kontrol negatif.

Pemeriksaan imunohistokimia ekspresi NF-kB pada hari ke-7: (G) kelompok kontrol positif, (H) kelompok CO, (I) kelompok C3, (J) kelompok kontrol negatif

Tanda panah menunjukkan sel yang positif mengekspresikan NF-kB yang ditandai dengan sitoplasma yang terwarnai coklat pada pemeriksaan imunohistokimia.

Gambar 2A menunjukkan hasil uji post hoc Tukey untuk pengamatan hari ke-3. Pemeriksaan imunohistokimia menunjukkan bahwa kelompok pengobatan C0 dan C3 menunjukkan efektivitas yang sama dalam menurunkan ekspresi NF-kB (Gambar 2B, C, D, dan F). Uji One Way ANOVA untuk ekspresi NF-kB diantara berbagai kelompok pada hari ke-7 juga menunjukkan perbedaan yang bermakna $(p=0,000)$. Uji post hoc Tukey menunjukkan perbedaan ekspresi NF-kB yang bermakna antara kelompok kontrol positif dan CO $(p=0,000)$, kontrol positif dan $C 1(p=0,000)$, kontrol positif dan $C 2(p=0,000)$, kontrol positif dan C3 $(p=0,000), C 0$ dan $C 2(p=0,013), C 0$ dan C3 $(p=0,005)$, dan $\mathrm{CO}$ dan kontrol negatif $(p=0,000)$. Tidak terdapat perbedaan yang signifikan antara kelompok C2 dan C3 $(p=0,994)$. Hasil tersebut menunjukkan bahwa kelompok pengobatan C2 dan C3 pada pengamatan hari ke-7 paling efektif dalam menurunkan ekspresi NF-kB. Gambar 2F menunjukkan hasil uji post hoc Tukey untuk pengamatan hari ke-7. Pemeriksaan imunohistokimia juga menunjukkan bahwa kelompok pengobatan kombinasi artemisin $0,12 \mathrm{mg} /$ hari dengan Moringa olifeira $15 \mathrm{mg} /$ hari (C3) lebih efektif dalam menurunkan ekspresi NF-kB dibandingkan dengan pemberian artemisin saja pada dosis 0,12mg/hariCO (Gambar 2G, H, I, dan J).

\section{EkspresiinOS}

Uji t-independen untuk rerata ekspresi iNOS pada jaringan otak mencit antara hari ke-3 dan ke-7 untuk tiap kelompok pengobatan menunjukkan perbedaan yang bermakna pada kelompok kontrol positif $(p=0,035), C 0(p=0,039), C 2$ $(p=0,029)$, dan C3 $(p=0,024)$. Tidak didapatkan perbedaan yang bermakna pada kelompok $\mathrm{C} 1(\mathrm{p}=0,159)$ dan kontrol negatif $(p=0,746)$. Uji One Way ANOVA untuk ekspresi iNOS diantara berbagai kelompok pada hari ke-3 menunjukkan perbedaan yang bermakna $(p=0,000)$. Uji post hoc Tukey menunjukkan perbedaan ekspresi iNOS yang bermakna antara kelompok kontrol positif dan $\mathrm{CO}$ $(p=0,000)$, kontrol positif dan $\mathrm{C} 1(p=0,000)$, kontrol positif dan C2 $(p=0,000)$, dan kontrol positif dan C3 $(p=0,000)$. Tidak didapatkan perbedaan yang signifikan antara kelompok C0 dan C1 ( $p=1,000)$, CO dan C2 ( $p=0,259)$, dan C0 dan C3 $(p=0,143)$. Hasil tersebut menunjukkan bahwa semua kelompok pengobatan pada pengamatan hari ke-3 memiliki efektivitas yang sama dalam menurunkan ekspresi iNOS.
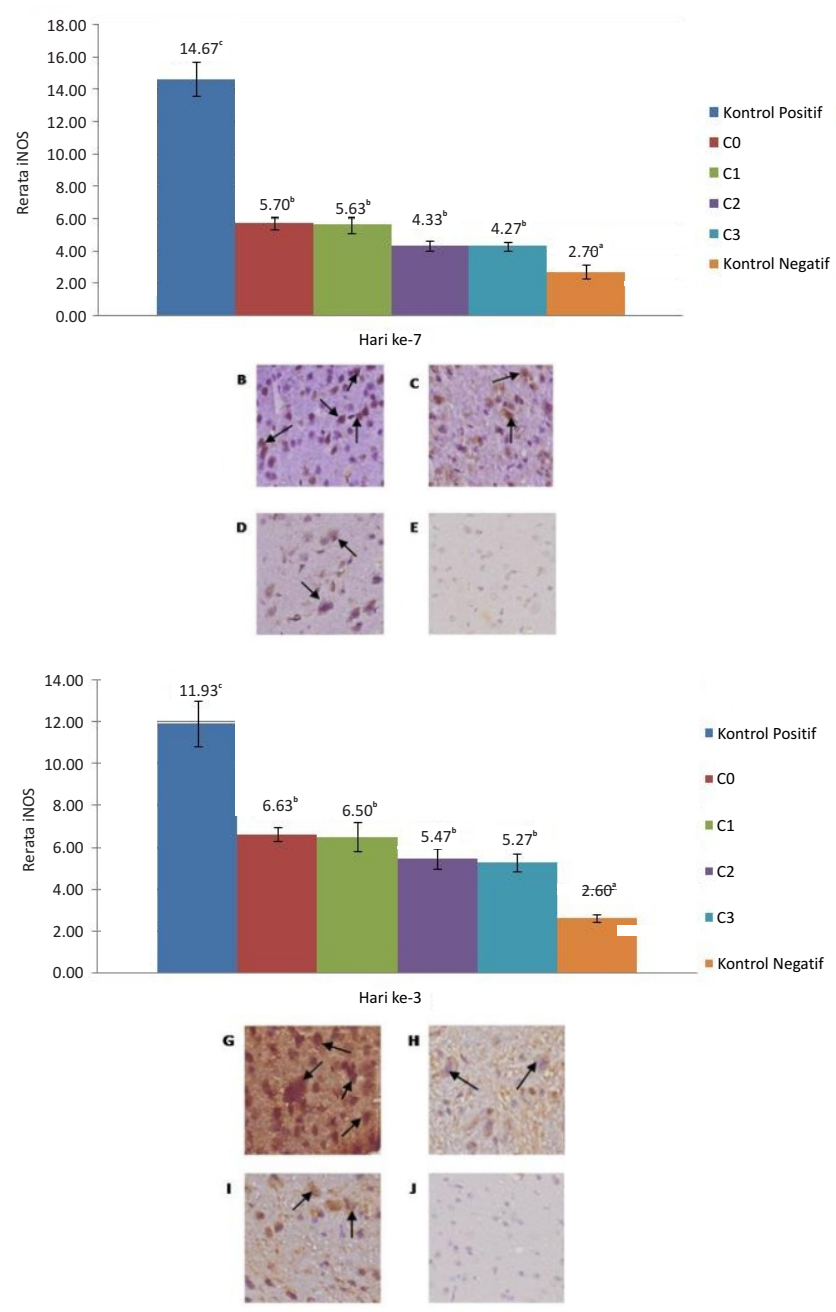

Gambar 3. Efektivitas kombinasi artemisinin dan ekstrak Moringa oleifera dalam menurunkan ekspresi iNOS.

\section{Keterangan:}

Mencit diberikan pengobatan artemisinin $0,12 \mathrm{mg} /$ hari (C0), kombinasi artemisinin $0,12 \mathrm{mg} /$ hari dan ekstrak Moringa oleifera 3,75mg/hari (C1), $7,5 \mathrm{mg} /$ hari (C2), dan $15 \mathrm{mg} /$ hari (C3), masing-masing pengobatan diberikan selama 3 hari dan 7 hari.

(A) Grafik perbedaan ekspresi iNOS pengamatan hari ke-3

(B) Pemeriksaan imunohistokimia ekspresi iNOS hari ke 3 kelompok kontrol positif, (C) kelompok CO, (D) kelompok C3, (E) kontrol negatif

(F) Grafik perbedaan ekpresi iNOS pada pengamatan hari ke-7

(G) Pemeriksaan imunohistokimia ekspresi iNOS pada hari ke-7 kelompok kontrol positif, (H) kelompok CO, (I) kelompok C3, (J) kontrol negatif.

Tanda panah menunjukkan sel yang positif mengekspresikan iNOS yang ditandai dengan sitoplasma yang terwarnai coklat pada pemeriksaan imunohistokimia. 
Gambar 3A menunjukkan hasil uji post hoc Tukey untuk pengamatan hari ke-3. Pemeriksaan imunohistokimia menunjukkan bahwa C0 dan C3 memiliki efektivitas yang sama dalam menurunkan ekspresi iNOS dibandingkan dengan kontrol positif (Gambar 3B, C, D, dan F). Uji One Way ANOVA untuk ekspresi iNOS diantara berbagai kelompok pada hari ke-7 juga menunjukkan perbedaan bermakna $(p=0,000)$. Uji post hoc Tukey menunjukkan perbedaan ekspresi iNOS yang bermakna antara kelompok kontrol positif dan CO $(p=0,000)$, kontrol positif dan $\mathrm{C} 1(\mathrm{p}=0,000)$, kontrol positif dan $\mathrm{C} 2(\mathrm{p}=0,000)$, dan kontrol positif dan $\mathrm{C} 3(\mathrm{p}=0,000)$. Tidak didapatkan perbedaan yang bermakna antara kelompok C0 dan C1 $(p=1,000)$, CO dan C2 ( $p=0,092)$, dan C0 dan C3( $p=0,073)$. Hasil tersebut menunjukkan bahwa semua kelompok pengobatan pada pengamatan hari ke-7 memiliki efektivitas yang sama dalam menurunkan ekspresi iNOS. Gambar 3F menunjukkan hasil uji post hoc Tukey untuk pengamatan hari ke-7. Pemeriksaan imunohistokimia menunjukkan bahwa pemberian artemisin dosis $0,12 \mathrm{mg} /$ hari (CO) dan kombinasi artemisin $0,12 \mathrm{mg} /$ hari dengan Moringa olifeira $15 \mathrm{mg} /$ hari (C3) memiliki efektivitas yang sama dalam menurunkan ekspresi iNOS dibandingkan dengan kontrol positif (Gambar 3G, H, I dan J).

\section{DISKUSI}

Malaria otak ditandai dengan kondisi iskemia otak yang diinduksi oleh proses cytoadherence eritrosit yang terinfeksi pada dinding pembuluh darah otak, rosetting atau autoagglutination eritrosit yang terinfeksi didalam darah sirkulasi, dan diikuti dengan sekuestrasi dari eritrosit yang terinfeksi kedalam jaringan otak (3). Iskemia otak sendiri akan menginduksi respon inflamasi yang berlebihan di jaringan otak dengan akibat terjadinya kematian neuron (21).

Proses inflamasi yang berlebihan dalam jaringan otak yang dimediasi oleh produksi sitokin dan radikal bebas yang berlebihan diinduksi oleh aktivasi NF-Kb (4). Protein ini diekspresikan oleh sel-sel kekebalan di otak, terutama oleh mikroglia dan astrosit. Protein ini penting untuk transkripsi sitokin proinflamasi di jaringan otak yang diaktivasi oleh berbagai macam stimuli, seperti infeksi dan stres oksidatif (15). Oleh karena itu, peningkatan ekspresi NF-KB pada jaringan otak mencit yang diinfeksi Plasmodium berghei akan mewakili terjadinya respon inflamasi yang berlebihan di jaringan otak tersebut. Analisis post hoc menunjukkan bahwa kombinasi artemisinin $0,12 \mathrm{mg} /$ hari dan ekstrak Moringa oleifera $3,75 \mathrm{mg} /$ hari, $7,5 \mathrm{mg} /$ hari, and $15 \mathrm{mg} /$ hari selama 3 hari tidak menunjukkan penurunan ekspresi NF-KB yang bermakna dibandingkan dengan pemberian artemisinin $0,12 \mathrm{mg} /$ hari selama 3 hari. Ketika pengobatan dilanjutkan sampai 7 hari, didapatkan penurunan ekspresi NF-kB yang bermakna pada kelompok yang diberikan kombinasi artemisinin $0,12 \mathrm{mg} /$ hari dan ekstrak Moringa oleifera $7,5 \mathrm{mg} /$ hari dan $15 \mathrm{mg} /$ hari. Hasil tersebut menunjukkan bahwa untuk menurunkan respon inflamasi yang berlebihan di jaringan otak, diperlukan pemberian kombinasi artemisinin 0,12mg/hari dan ekstrak Moringa oleifera $7,5 \mathrm{mg} /$ hari selama 7 hari.

Aktivasi NF-kB bisa terjadi melalui jalur klasik maupun jalur alternatif (17). Proses pengiriman sinyal untuk aktivasi NF-KB melalui jalur klasik diperantarai oleh interaksi antara ligand dengan reseptor TNF tipe 1 atau tipe 2 (TNFR1/2), reseptor sel T ( $T$-cell receptor/TCR), reseptor sel B (B-cell receptor/BCR), dan Toll-like receptor (TLR). Disisi lain, proses pengiriman sinyal untuk aktivasi NF-KB terjadi melalui jalur alternatif diperantarai oleh aktivasi anggota dari reseptor keluarga TNF tertentu, seperti reseptor $\beta$ limfotoksin (lymphotoxin $b$ receptor/LT $\beta R$ ), faktor pengaktivasi sel $B$ yang masuk dalam reseptor keluarga TNF (B-cell activating factor belongs to TNF family receptor/BAFF-R), CD40, dan CD30 (17). Setelah terjadi aktivasi reseptor, baik melalui jalur klasik maupun jalur alternatif, akan diikuti dengan proses aktivasi mitogen-activated protein kinase (MAPK). Terdapat tiga kelompok MAPK yang memediasi aktivasi NF-KB pada mamalia, yaitu ERK, JNK/SAPK, dan p38. Aktivasi dari MAPK akan memediasi terjadinya fosforilasi inhibitor NF-kB (IkB) dan pelepasan NF-kB yang teraktivasi. Respon penting yang terjadi akibat aktivasi NF-kB adalah produksi berbagai macam sitokin proinflamasi (18).

Hasil penelitian ini menunjukkan bahwa pemberian kombinasi artemisinin 0,12mg/hari dan ekstrak Moringa oleifera $7,5 \mathrm{mg} /$ hari selama 7 hari menurunkan ekspresi NF-KB secara bermakna dibandingkan dengan pemberian artemisinin 0,12mg/hari selama 7 hari. Mekanisme kerja ekstrak Moringa oleifera dalam menghambat ekspresi NF$\mathrm{kB}$ saat ini masih belum diketahui. Berdasarkan landasan teori yang telah disampaikan sebelumnya, diduga bahwa aktivitas antiinflamasi ekstrak Moringa oleifera bisa pada proses penghambatansalah satu atau lebih dari tahaptahap aktivasi NF-KB, baik melalui penghambatan pada proses interaksi antara reseptor dan ligand, penghambatan aktivasi MAPK, atau penghambatan fosforilasi IkB. Perlu dilakukan penelitian lebih lanjut untuk membuktikan hal tersebut.

Lisis eritrosit terinfeksi Plasmodium berghei dalam sirkulasi darah sistemik akan menyebabkan lepasnya glycosilphosphatidylinositol (GPI) (3). Protein tersebut mampu merangsang aktivitas makrofag untuk memproduksi sitokin-sitokin proinflamasi, seperti IL-1, IL6 , dan TNF- $\alpha$. Pada kasus malaria serebral, sitokin-sitokin tersebut dan GPI dapat mengalami translokasi kedalam jaringan otak dan mampu menginduksi aktivasi NF-kB pada sel-sel kekebalan dijaringan otak dengan akibat dihasilkannya sitokin proinflamasi didalam jaringan otak (15). Berdasarkan landasan teori tersebut, jika kombinasi artemisinin dan ekstrak Moringa oleifera mampu menurunkan derajat parasitemia, maka kombinasi obat tersebut juga akan mampu menurunkan lepasnya GPI dan sitokin proinflamasi sehingga mampu menurunkan ekspresi NF-kB dijaringan otak mencit model malaria.

Analisis post hoc pada pengamatan hari ke-3 menunjukkan bahwa pemberian kombinasi artemisinin $0,12 \mathrm{mg} /$ hari dan ekstrak Moringa oleifera $7,5 \mathrm{mg} /$ hari dan $15 \mathrm{mg} /$ hari secara efektif menurunkan derajat parasitemia. Disisi lain analisis post hoc pada pengamatan hari ke-7 menunjukkan bahwa pemberian kombinasi artemisinin $0,12 \mathrm{mg} / \mathrm{hari}$ dan ekstrak Moringa oleifera $15 \mathrm{mg} /$ hari lebih efektif dalam menurunkan derajat parasitemia. Hal ini berarti bahwa pemberian kombinasi artemisinin $0,12 \mathrm{mg} / \mathrm{hari}$ dan ekstrak Moringa oleifera $15 \mathrm{mg} /$ hari selama 7 hari merupakan pengobatan yang paling efektif dalam menurunkan derajat parasitemia. Masih diperlukan penelitian lebih lanjut dengan menggunakan ekstrak Moringa oleifera dengan dosis lebih tinggi untuk menurunkan derajat parasitemia hingga mencapai $0 \%$. 
Penurunan derajat parasitemia pada penelitian ini setidaknya bisa membantu menjelaskan bagaimana mekanisme penurunan ekspresi NF-KB dalam penelitian ini.

Seperti yang telah disampaikan sebelumnya, aktivasi NFKB didalam sel-sel kekebalan diotak akan menyebabkan produksi sitokin proinflamasi, seperti iNOS, COX-2, TNF- $\alpha$, IL-1 $\beta$, IL-6, dan sebagainya (19). Salah satu mediator inflamasi penting yang dihasilkan oleh mikroglia melalui aktivasi NF-kB adalah protein iNOS. Protein ini memediasi produksi nitric oxide (NO), yang selanjutnya akan bereaksi dengan $\mathrm{O}_{2}$ untuk membentuk peroksinitrit (ONOO) dan radikal hidroksil yang bersifat reaktif. Produksi NO secara berlebihan akan membahayakan neuron, karena akan menyebabkan disfungsi neuron dan apoptosis (20). Protein iNOS yang dihasilkan secara berlebihan akan mengaktivasi mikroglia dan selanjutnya akan membangkitkan proses kaskade inflamasi. Sekali diekspresikan, iNOS bentuk aktif akan terus ada selama periode waktu yang lama sampai mengalami proses degradasi (15). Berdasarkan landasan teori tersebut, penelitian ini juga ditujukan untuk menguji efek kombinasi artemisinin dan ekstrak Moringa oleifera dalam menurunkan respon inflamasi yang berlebihan melalui

\section{DAFTAR PUSTAKA}

1. World Health Organization. World Malaria Report: 2012. Switzerland: WHO Press; 2012; pp. 1-2, 39-44.

2. White NJ. Plasmodium knowlesi: The Fifth Human Malaria Parasite. Clinical Infectious Disease. 2008; 46(2): 172-173.

3. Idro R, Jenkins NE, and Newton NE. Pathogenesis, Clinical Features, and Neurological Outcome of Cerebral Malaria. The Lancet Neurology. 2005; 4(12): 827-840.

4. Uffort DG, Grimm AE, and Ellerhorst JA. NF-kB Mediates Mitogen-Activated Protein Kinase PathwayDependent iNOS Expression in Human Melanoma. Journal of Investigative Dermatology. 2009; 129(1): 148-154.

5. Liu L, Huq S, and Xu W. Targeting Cyclooxygenase and Nitric Oxide Pathway Cross-Talk: A New Signal Transduction Pathway for Developing More Effective Anti-Inflammatory Drugs. Current Signal Transduction Therapy. 2009; 4(1): 66-75.

6. Brown GD. The Biosynthesis of Artemisinin (Qinghaosu) and the Phytochemistry of Artemisia Annua L. (Qinghao). Molecules. 2010; 15(11): 76037698.

7. Saphiro TA and Goldberg DE. Chemotherapy of Protozoal Infections: Malaria. In: Brunton LL, Lazo JS, Parker KL (Ed). Goodman and Gilman's the Pharmacological Basis of Therapeutics 11th edition. USA: McGraw-Hill Inc; 2006; pp. 1069-1092.

8. Krishna S, Uhlemann AC, and Haynes RK. Artemisinins: Mechanisms of Action and Potential for Resistance. Drug Resistance Updates. 2004; 7(4-5): 233-244.

9. Patel JP, Gami B, and Patel K. Evaluation of in Vitro Schizonticidal Properties of Acetone Extract of Some Indian Medicinal Plants. Advances in Biological Research. 2010; 4(5): 253-258. penghambatan ekspresi iNOS.

Analisis post hoc menunjukkan bahwa pemberian kombinasi artemisinin 0,12 mg/hari dan ekstrak Moringa oleifera $3,75 \mathrm{mg} /$ hari, $7,5 \mathrm{mg} /$ hari, dan $15 \mathrm{mg} /$ hari, baik selama 3 hari maupun 7 hari tidak memberikan penurunan ekspresi iNOS secara bermakna dibandingkan dengan pemberian obat standar artemisinin $0,12 \mathrm{mg} /$ hari. Temuan ini membuktikan bahwa ekstrak Moringa oleifera tidak meningkatkan efek artemisinin dalam menurunkan respon inflamasi melalui penghambatan ekspresi iNOS. Penelitian lebih lanjut perlu dilakukan untuk menguji apakah kombinasi artemisinin dan ekstrak Moringa oleifera mampu menghambat sitokin proinflamasi lainnya secara signifikan.

Hasil penelitian ini membuktikan bahwa pemberian kombinasi artemisinin 0,12mg/hari dan ekstrak Moringa oleifera $15 \mathrm{mg} /$ hari selama 7 hari lebih efektif dalam menurunkan aktivasi NF-KB dibandingkan dengan pemberian artemisinin $0,12 \mathrm{mg} /$ hari sebagai obat standar. Meskipun demikian, pemberian kombinasi artemisinin $0,12 \mathrm{mg} /$ hari dan ekstrak Moringa oleifera $15 \mathrm{mg} /$ hari, baik selama 3 hari maupun 7 hari, tidak lebih superior jika dibandingkan dengan pemberian artemisinin $0,12 \mathrm{mg} / \mathrm{hari}$ sebagai obat standar dalam menurunkan ekspresi iNOS.

10. Sen CK and Packer L. Antioxidant and Redox Regulation of Gene Transcription. The Journal of the Federation of American Societies for Experimental Biology. 1996; 10(7): 709-720.

11. Pari L, Karamac M, Kosinska A, Rybarczyk A, and Amarowicz R. Antioxidant Activity of the Crude Extracts of Drumstick Tree (Moringa Oleifera Lam.) and Sweet Broomweed (Scoparia Dulcis L.) Leaves. Polish Journal of Food and Nutrition Sciences. 2007; 57(2): 203-208.

12. Blazquez K, Moll K, Ljungstrom I, Petmann, Scherf A, and Wahlgren M. Methods in Malaria Research. 5th edition. Paris: BioMalPar; 2008: pp.15.

13. Sachan D, Jain SK, and Singh N. In Vitro and In Vivo Efficacy of Moringa oleifera Plant Constituents in Urolithiasis as Antilithiatic Drugs. International Journal of Pharma Sciences and Research 2011; 2(7): 1638-1644.

14. Lou J, Lucas R, and Grau GE. Pathogenesis of Cerebral Malaria: Recent Experimental Data and Possible Application for Human. Clinical Microbiology Reviews. 2001; 14(4): 810-820.

15. Kleinert H, Schwarz PM, and Forstermann U. Regulation of the Expression of Inducible Nitric Oxide Synthase. The Journal of Biological Chemistry. 2003; 384(10-11): 1343-1364.

16. Kasolo JN, Bimenya GS, Ojok L, Ochieng J, and OgwalOkeng JW. Phytochemicals and Uses of Moringa Oleifera Leaves in Ugandan Rural Communities. Journal of Medicinal Plants Research. 2010; 4(9): 753757.

17. Nishikori M. Classical and Alternative NF-kB Activation Pathways and Their Roles in Lymphoid Malignancies. Journal of Clinical and Experimental Hematopathology. 2005; 45(1): 15-21

18. Kim DH, Kim HK, Park S, et al. Short-Term Feeding of 
Baicalin Inhibits Age-Associated NF-Kb Activation. Mechanisms of Ageing and Development. 2006; 127(9): 719-725.

19. Lin HY, Tang CH, Chen YH, et al. Peptidoglycan Enhances Proinflammatory Cytokine Expression Through the TLR2 Receptor, Myd88, Phosphatidylinositol 3-Kinase/AKT and NF-Kappab Pathways in BV-2 Microglia. International
Immunopharmacology. 2010; 10(8): 883-891.

20. Won SJ, Kim DY, and Gwag BJ. Cellular and Molecular Pathways in Ischemic Neuronal Death. Journal of Biochemistry and Molecular Biology. 2002; 35(1): 6786

21. Lindsay KW, Bone I. Neurology And Neurosurgery Illustrated. 4th edition. China: Elsevier Limited; 2004; p. 242-243. 